\title{
THE NARRATIVES OF ORIGIN AND MIGRATION OF THE TIV PEOPLE (OF NIGERIA) AS AN INDIGENOUS INTERPRETIVE RESOURCE FOR THE INTERPRETATION OF THE BOOK OF EXODUS
}

\author{
Jonathan T Weor \\ Department of Old Testament \\ Stellenbosch University
}

\begin{abstract}
Gerald West has drawn the attention of Biblical scholars in Africa to the usefulness of indigenous reading resources in Africa. This essay will take as its point of departure West's persuasive argument that indigenous interpretive resources can enrich the interpretive work of trained biblical scholars. The essay will attempt to show how narratives of the origin and migration of the Tiv people from the Swem Mountain in Cameroon to north central Nigeria influence and elucidate their understanding and interpretation of the origin and religion of the people of Israel. Specifically, the essay will show how this understanding further influenced the Tiv people's interpretation of the book of Exodus. Suggestions will be made on how Biblical scholars in Nigeria could utilize this interpretive resource in their reading encounter with those that West describes as ordinary readers of Tiv extraction.
\end{abstract}

Key concepts: Book of Exodus, Identity, Narratives, Tiv

\section{Introduction}

Gerald West (1991b: 87-110) in his Biblical hermeneutics of liberation stressed the need of incorporating the ordinary reader of the Bible in the process of Biblical interpretation. The ordinary reader in his/ her context refers to the untrained Biblical readers, the illiterates, the poor, and the marginalized people. West says the ordinary reader in Africa can understand the Bible better through experience of past history (1991:87-110; 1992:35-49; 1999a:64-65). He also argued that the "ordinary reader" is "unstable", just as the historical situation of all black interpreters makes it difficult for them to offer a stable interpretation. Therefore West contends that the unstable memoirs of the poor and oppressed can be recovered through the "behind-the-text-reading" of Scripture (West 1999a: 64-65; Akper 2005:5).

West has argued consistently for an equal place to be given to literary modes of reading which he says are more egalitarian and empowering than the socio-historical approaches especially when reading with the ordinary reader of the Bible (2004:128). He also emphasize in the same work that he would not want to privilege any historical modes of reading (2004:131).

My own discussions concentrate on his initial views of the socio-historical interpretation of the Bible which builds on the experience of the ordinary readers, who in my research are the Tiv people of north central Nigeria. They are considered to be ordinary readers of the book of Exodus in the sense that many are barely literate, untrained theologically, non original recipients of the book of Exodus and traditionally inclined towards worship. 


\section{The Relevance of History in Biblical Interpretation to Ordinary Tiv Readers in Africa}

As McKnight (1998: 4-5) indicated the Bible emerged from the real experiences of real people and that the various parts of the Bible could also be set in particular historical contexts. History according to McKnight can be seen as the movement of the divine spirit itself and of events viewed in terms of universal historical progress. Historical criticism based on McKnight's view will enable a believing Tiv critic to note the witness of the divine spirit in historical witness of Scripture. That is to say what they have known in the past would serve as the bedrock to what they may come to know from the Bible later.

Tiv people of north central Nigeria, described in this paper as the ordinary readers, have a peculiar history of origin which gave rise to their knowledge of the supreme God whom they believe is at work in creation and needs to be approached in humility in times of difficulty. The popular story of origin contends that the Tiv people were driven from their mythical home beyond the waters somewhere to the east of the Cameroon Mountains by the Ugenyi people who were considered to be their enemies.

As they were in headlong flight with their enemies in close pursuit, they came across the great waters of river Aya which they could not safely cross. At this point in time the Tiv people were stranded and had no way to cross the river in escape of their enemies. According to legend a friendly green snake called Ikyarem came by and stretched itself across the river. This enabled the Tiv people to cross safely on its back to the other side of the river from where they journeyed through the South and West, fighting enemy upon enemy on the way. Finally they reached the Benue province of north central Nigeria where they are now settled permanently.

Tiv tradition describes how they, on their way home from the Cameroon Mountains had to pass through the Swem Mountain, in the east of Cameroon. There they rested for a while and celebrated their victories and freedom from of their enemies. They then picked some "Celts stones" called ajembe a Aondo ('axes of God") which are believed to be stones dropped down by God through lightening and thunder.

They also picked some leaves of the tree that was assumed to have been struck down by thunder and lightning. In addition they got some of its ashes and put all in a decorated pot which they obtained from the same Swem Mountain and journeyed with it as their god and protector.

The Swem Mountain is held in legend as a sacred place, almost the "Sinai" of the ancestors and unseen spirits. It is a mysterious source of tsav (witchcraft) and an ordinary Tiv reader of the Bible considers the Swem pot and mountain as symbols of tribal unity. The power of the remote ancestors is symbolized by the imborivungu (pipe rites) that refer to a mythological god who is represented by the Swem. Both Swem Mountain and Swem pot are mysterious sources from which the mbatsav (witches and wizards) renew or increase their vital powers so as to put right their land.

To an ordinary Tiv man, the Swem pot and the Swem Mountain are of significant value in their everyday lives. The pot, which has to be prepared by a man endowed with the necessary tsav (witchcraft), is used for oath taking and to ascertain truth. This Swem pot can only be handled by "spiritual" people, who have extraordinary powers. It is similar to the commandments given to Moses on Mount Sinai (Exodus 20:1-17) when only Moses, empowered by the spirit of God, had to climb up the holy mountain of Sinai to collect the tablets of the commandments for the entire Israelite community. Laws concerning 
marriages and sexuality, worship of gods and idols, justice, sacrificial acts, cult practices, divination, and taboos are all contained in the Swem pot that functions as the Tiv law book.

According to Downes (1971:22-23) the actual and visible Tiv cosmos (tar) is seperated from the mystical and unseen part of it by means of water. Beyond the water exists the vague and immaterial world of mbatsav (witchcraft). This nether world is where good and evil exist - echoes of the Garden of Eden with a snake as guardian! It is the very place from which the tribe was driven by an unknown enemy. This description brings to mind the subterranean river of the ancient Egypt linked to the underworld where the dead live.

The Tiv people relates this river to the situation in Eden and the persecuted tribe to their migration story. According to this migration narrative they were running away from their enemies and came to a great river in flood called Aya and had no means of crossing the river. At the point when they were stranded with their enemies following them, a harmless green snake (Ikyarem) entwined itself in the branches of trees on both banks of the river and the people crossed in safety. However, when the pursuers arrived and attempted to follow the Tiv, the snake released its coils and dropped them into the water.

This story, as would be expected, is suggested by most Tiv to refer to some actual historical incident but the mythical connection of the story with the unseen world is sufficiently obvious (Downes 1971:23). The Ikyarem snake in particular, is seen as a taboo by the Tiv people that is never to be killed but rather regarded as a saviour or friend. This green snake reminds one of the rod of Moses that was transformed into a snake to convince the pharaoh to free the Israelites from bondage (Ex 4:2-5; 7:8-13; 8-11). It is also similar to the snake of the Garden of Eden and the Uraeus snake in the representations of the Egyptian netherworld (Downes 1971:23). This brief comparison between the Tiv narratives concerning origin and migration and the Exodus narratives in the Old Testament has revealed remarkable similarities that can be explored in further attempts to contextualize the interpretation of the Exodus amongst the Tiv.

This comparison between the Tiv and Exodus narratives indicates the potential of historical methodology as an effective heuristic tool to facilitate an adequate understanding of the book of Exodus amongst ordinary Tiv readers. Efird (1984:10-11) argues historical methodology is the keystone of the modern academic study of the Bible. The historical quest entails answering as best as one can question such as: 'Who? What? Where? When? Why? and to whom?' The strength of the historical approach according to Efird rests in its emphasis on uncovering and discovering the older settings and meanings of these documents. The potential meaning of a text he contends can best be understood when that text is interpreted in its own historical setting.

The modern secularized academic community runs the risk of becoming detached from the biblical text by failing to appreciate the biblical books as products of and for faith communities. Therefore the comparison of the origin and migration narratives enables the ordinary Tiv reader of the Bible to comprehend events in the Bible that are similar to events described in their own traditional narratives.

\section{The Role of Socio-Culture Values in Biblical Interpretation to Ordinary Tiv Readers in Africa}

Culture plays an important role in the understanding of the Bible and this includes the ordinary readers of the Bible. Justin Ukpong (1999: 18) calls for enculturation hermeneutics as a method of Biblical interpretation by communities of ordinary readers.

He defines enculturation hermeneutics as a contextual hermeneutical methodology that 
seeks to make any community of ordinary readers and their socio-cultural context to become the subject of interpretation of the Bible. This methodology he says has the task of appraising the cultural dimensions of the Bible in respect of its attitude to and evaluation of other people and cultures. Ukpong's point of his departure is that the Bible is not culturally and ideologically innocent as a text. Though the Bible is the word of God it is also written in human language that is intertwined with culture, ideology, world view, perspective and values.

Ordinary Tiv readers of the Bible, when placed in the centre of Biblical interpretation with due consideration to their world-iew and cultural values, will understand the Bible better. For example reflecting on the Israelites as being farmers will enable the Tiv understanding of the Israelite settlements and economic resources because the Tiv people are also a farming community. Applying this comparative method, however, require much ethical sensitivity since the consideration of other peoples and cultures involve dealing with it in such a way that it maintains biblical values of love, respect for others, justice and peace.

Contributing on the same issue of the roles of culture in the interpretation of the Bible to the ordinary Tiv man/woman in Africa, Larkin (1988:192-193) says culture was ordained at creation by God with specific tasks such as: filling, subduing, ruling the earth (Gen. 1:28), as well as working and taking care of God's physical creation ( Gen. 2:15). There were also values and behaviour patterns such as obedience to God under threat of punishment (Gen.2: 16-17) and structures, including the family social order. Larkin defines culture as an integrated pattern of socially acquired knowledge, particularly ideas, belief, and values mediated through language, which a group of people uses to interpret their experience and to generate patterns of behaviour on different levels: technological, economic, social, political, religious, and artistic so that it can survive by adapting to relentlessly changing circumstances.

To disassociate ordinary Tiv readers of the Bible from their cultural background, a background which functions as a text to them and is mirrored in any biblical interpretation, makes the understanding much more complex for them. For instance, ordinary Tiv readers consider their land (tar) as the only place where they are known and registered as complete citizens of the society. Social activities, security, religious worship, prestige, prosperity, and freedom are only guaranteed in their land (tar) where the ancestors who are considered as their immediate protectors dwell.

The cosmos or world called tar by the ordinary Tiv readers of the Bible is concrete and contain both animate and non-animate things that exist for the benefit of humankind. In addition one must also consider the unseen powers or spirits that regulate the affairs of humankind (body and soul) and who are part of the ancestor traditions that are embedded in the tar on which they live. Should one place this ordinary Tiv reader of the Bible in the centre of biblical interpretation, particularly Exodus as a text existing with the cultural values of the Israelites who were in bondage in Egypt, they will understand better why the Israelites were calling continuously to God for deliverance to have freedom of worship in their own land.

AC Edward (1983:459-480) also comments that the unity and harmony of Tiv values do not lie in political institutions nor in formal rituals but in their beliefs about the magical power of tsav (witchcraft) which is both the correlative of the authority of elders and the anti-social form of occult malice. Tsav is culturally controlled from getting out of hand by the Swem pot through taking oaths. The Swem pot is further linked to an outer circle of Tiv belief connected with adzov (sprites), the shape changers and the mysterious Swem Mountain. All these cultural beliefs establish self-control among Tiv people similar to the covenant relationship of the Israelites with God that included the Ark of covenant, and the Sinai commandments. These elements were shaping their social, cultural, and religious 
lives in a way similar to the Tiv cultural, social, and religious understanding of the Swem pot. When this socio-cultural aspect of Tiv people is neglected in their Biblical interpretation they would not consider it as being authentic since their comparative knowledge about it will be lacking.

\section{The Influence of Pre-Religious Beliefs on the Ordinary \\ Tiv Reader of the Bible in Africa}

The religious ideas and belief of the Tiv people are also backed up by their culture which has to do with the worship of idols as symbols of worship of the God in the sky. Tiv people in their indigenous way of worship were always conscious of maintaining a stable religious life. A search for this stability was normally achieved through divination performed by elderly people in the family, clan, and tribe called diviners. This act is a good way of helping the ordinary Tiv reader of the Bible to find a way of getting back to a more normal life situation in times of trouble. It serves the purpose of knowing which supernatural agency was to be addressed, what object to be used and prayer or prayer types to be offered respectively.

The ordinary Tiv reader of the Bible believes in the existence of the high God in the sky and ascribe to him the attributes of might and omnipresent. They believe that God created the world but has left it in control of the unseen spirits. Sacrifices were therefore, offered to him through the idol gods more accessible to them. They believe that the sky God hates evil, thus approaching him usually cases a lot of cleansing and other rituals. The Swem pot is also highly respected as the supreme controller of all evils. Once this indigenous idea of the worship of God among the ordinary Tiv readers is related to a similar depiction of the worship of God in the Bible, one can anticipate establishing a more adequate interpretation of the Bible that makes sense to its Tiv audience. For instance, Tiv people were approaching the sky God through diviners, idols, sacrificial rites and rituals in a way similar to the Israelites who approached the heavenly God through Moses, burnt offerings, and other rituals.

\section{How an Ordinary Tiv Reader in Africa can Interact with the Book of Exodus in his own Way(s)}

Masenya (1999:238) said one's reading is shaped by his or her experience and that, the experience of the reader will always play a role in a reader's encounter with the Bible. The ordinary Tiv reader of the Bible considers their own past experience therefore, to be significant for the interpretation of the Bible. The relevance and significance of the Bible can be comprehended in relation to the past experiences of Tiv readers and the apparent similarities of their origin narratives with that of the Biblical Exodus. Relating the Bible to the Tiv people in terms of their past social, cultural, religious and historical experiences will enable them to generate new meaning and understanding. Y Gitay (2005) called for the appreciation of inter-textual allusions used in the interpretation of the Bible. This also holds true for Exodus where ordinary readers will find Biblical events similar to their own past experiences and this will enable a more adequate understanding of the Biblical text.

The Tiv narratives concerning origin manifested the great power of Swem, the unseen and supreme spirit which made them to journey courageously to north central Nigeria, that became their place of origin. Their encounter with enemies on their way home and all the victorious battles fought are attributed to the power of the Swem pot that enabled its supernatural agents (witches and wizards) who manipulated nature in favour of the Tiv 
people. To the ordinary Tiv readers the Swem pot, obtained from the Swem Mountain, serves as a source of commandments for their social and religious living.

Laws concerning sexuality, neighbourliness, marital affairs, religious worship, justice, sacrificial acts, sorcery, witchcraft practices, wars, kingship, and taboos are all embedded in the Swem pot, the indigenous "bible" and law book of the Tiv people containing stones, ashes, and leaves all picked from the Swem Mountain in the Cameroon area. This can be read parallel to the Ten Commandments given to the Exodus people on Mount Sinai (Rubingh: 1969:80). The skull of Takuluku, a father to Tiv people, was brought back from the Swem Mountain and is preserved in the Swem pot in powdered form. This resembles the bones of Jacob in the Bible taken home from Egypt by the Exodus people (Ex 13:19). The ritual called akombo is performed with an animal to cure a disease, or to appeal to the gods. The sacrifice is eaten by the initiators of the ritual in the house or in a secret place with the blood rubbed on a carved or moulded idol and the bones preserved to initiate offspring. It is clear that the akombo ritual has surprising similarities with the celebration of the Passover in Exodus.

The crossing of the river Aya on the back of Ikyarem (the green snake), by the Tiv people alludes to the crossing of the Re(e)d Sea by the Exodus people (Ex 13:17-15:21). Tiv people sang a song and uttered a proverb after crossing the river Aya: ka we per yande la u yila ambe iwa ("when you cross the other side you can insult the crocodile"). The song continues: nyian alu ikur ior a bam se hoon se kpe - sang twice ("today if any tribe will provoke us we are going to die"). This song is similar to the victorious song of the Exodus people after crossing the Red Sea (Ex. 15:1-21). The Swem pot also resembles the ark of covenant in Exodus. The Tiv shrine, with an idol placed in there, relates to the Exodus tabernacle symbolizing the presence of God (Ex 35-40). Tiv people have the green snake as the covenant sign just as circumcision was expected of the Exodus people as a covenant symbol. The acts by the mbatsav (witches and wizards) in times of trouble correspond with acts of God through plagues in Egypt (Thomas 1996: 3-4).

\section{Conclusion}

The contribution has argued that the Tiv people can more adequately understand the book of Exodus by relating their origin and migration narratives with the biblical events of Exodus. Historical interpretive means are suggested as heuristic tools for ordinary readers to interact with the Bible. This point of view is suggested because it allows access to social, cultural, and religious aspects of human life embodied in experiences of the past. Biblical scholars in Nigeria, by employing the historical and comparative methodologies of biblical interpretation, can stimulate a more appropriate engagement by ordinary readers with the Bible and this approach will allow a relevant and contextual theological interpretation to develop.

\section{BIBLIOGRAPHY}

Akper, GI 2005. "The role of the ordinary reader in Gerald West's hermeneutics." Scriptura 88: 1-13.

Downes, RM 1971. Tiv Religion. Ibadan: University Press.

Dozeman, T 1996. God at power in the Exodus. New York: University Press.

Edward AC 1983. "Seeing, Believing, Doing: The Tiv Understanding of Power", Anthropos 78: 3-4.

Efird, JM 1984. How to Interpret the Bible. Atlanta: John Knox Press. 
Eugene, R 1969. Sons of Tiv. Grand Rapids: Baker Book House.

Gitay, Y 2005. Oral presentation: University of Stellenbosch, South Africa.

Larkin, WJ 1988. Culture and biblical hermeneutics: interpreting and applying the authoritative Word in a relativistic age. Grand Rapids: Baker Book House.

Masenya, MJ 1999. "Biblical Authority and the Authority of Women's Experiences: Whither Way?" Scriptura 70: 229-240.

McKnight, EV 1985. The Bible and the Reader: An Introduction to Literary Criticism. Philadelphia: Fortress.

Mosala, IJ 1989. Biblical Hermeneutics and Black Theology in South Africa. Grand Rapids: Eerdmans.

Soulen, RN and Soulen, RK 2001. Handbook of Biblical Criticism. Louisville: Westminster.

Ukpong, JS 1995. "Reading the Bible with African Eyes: Inculturation and Hermenutics". Journal of Theology for Southern Africa 9: 3-14.

Ukpong, JS 1999a. "Models and Methods of Biblical Interpretation in Africa". Neue Zeitschrift Missions Wissenschaft 55: 4.

Ukpong, JS 1999b. "Can African Old Testament Scholarship escape the historical critical approach". Newsletter on African Old Testament Scholarship 7: 2-5.

Ukpong, JS 2002. Inculturation hermeneutics: an African approach to biblical interpretation. Grand Rapids: Eerdmans.

West, GO 1991a. Biblical Hermeneutics of Liberation: Modes of Reading the Bible in the South African Context. Pietermaritzburg: Cluster Publications.

West, GO 1991b. "The Relationship between the Different Modes of Reading the Bible and the ordinary Reader". Scriptura 39: 87-110.

West, GO 1992. "Interesting and Interested Readings: Deconstruction, the Bible, and the South African context." Scriptura 40: 35-49.

West, GO 1992a. Recovering the Suppressed Past and Reconstructing the Future: Historical Consciousness, Biblical and Theological Liberation Hermeneutics. Unpublished paper. Pretoria: Human Sciences Research Council, Centre for Research Methodology.

West, GO 1992b. "Some Parameters of the Hermeneutical Debate in the South African Context". JTSA 80: 3-13.

West, GO 1995. Biblical Hermeneutics of Liberation: Modes of Reading the Bible in the South African Context. Pietermaritzburg: Cluster Publications.

West, GO 1995. "Constructing Critical and Contextual Reading with Ordinary Readers. Mark 5:21-6:1.” JTSA 89: 60-69.

West, GO 1999a. The Academy of the poor: Towards a Dialogical Reading of the Bible. Sheffield: Sheffield Academic.

West GO 2004. "Historicity of Myth and the Myth of Historicity: Locating the Ordinary African 'Reader' of the Bible in the Debate” Neotestamentica 38(1): 127-144. 